\title{
Does the Current Distribution of Fruit Commodities in North Sumatra Help to Enhance the Regional Economic Development?
}

\author{
Dany Juhandi ${ }^{1}$, Ardian Elonard Purba ${ }^{2}$ \\ \{dany.juhandi@wbi.ac.id ${ }^{1}$ \} \\ Politeknik Wilmar Bisnis Indonesia, Indonesia ${ }^{1,2}$
}

\begin{abstract}
Fruit commodity is one of the most imported agricultural commodities. However, the government did not pay enough attention to agricultural policies for this commodity. Farmers also prefer to plant food and plantation commodities. Meanwhile, increasing consumption of fruits creates opportunities for farmers and the government to meet domestic demand. It increases due to the consumption factor of the population. Fruit consumption is currently showing an increasing trend because public awareness to consume fruits continues to increase. To meet domestic demand, the fruit market is filled with imported fruits. We need an appropriate development plan for fruit commodities which has an impact on regional economic development. This study aims (1) to analyze potential fruit commodities in North Sumatra, (2) to analyze specialization and localization of fruit commodities, and (3) to analyze priority fruit commodities in North Sumatra. The research methodology used in this paper is quantitative descriptive using secondary data from 2017 2018. The results of the study show that (1) each district in North Sumatra has a very varied fruit commodity base, (2) there are no districts in North Sumatra that specialized in producing certain fruit commodities, (3) the priority fruit commodities are still monotonous. Planning of fruit commodities development has not been specialized so that the objectives of regional economic development based on horticultural commodities are difficult to achieve.
\end{abstract}

Keywords: Regional Economic Development

\section{Introduction}

Fruit commodity is one of horticulture commodity that is less considered compared to food commodities such as rice, corn, and soybeans. It happens because government policy focuses more on food commodity than horticulture commodity. Government policy about horticultural commodities only set about import restrictions, such as Minister of Agriculture Regulation (Permentan) No. 42 of 2012.

Fruit commodities import has been limited because to prevent and inhibit the new plant pests [1]. Meanwhile, in developing countries, the need for horticultural commodities continue to increase every year. Even, the needs of the world to fruits experiencing a deficit [2]. It all happens because the consumer preferences are shifting to healthy food [3]. This is an opportunity for Indonesia as a developing country with a tropical climate to increase production and meet the needs of world's horticulture commodities. If production and export of this commodities is developed, it will give a positive impact to Indonesian economy. 
The contribution of fruit commodities has not been optimal because its trade balance shown a deficit. It happens because the need for domestic fruits is dominated by imported commodities. If we increase the export of fruit commodities, it will create a surplus in trade balance [4]. Fruit commodities in Indonesia have a relatively higher price compared to the same commodity from other countries. This is due to the low efficiency in the production process and the high logistic costs of this commodity.

The contribution of those commodities in the Gross Regional Domestic Product (GRDP) of the Agricultural Sector in North Sumatra Province is only10.8\% lower than food and plantation commodities, $16.54 \%$ and $62.65 \%$ [5]. The export performance of fruit commodities in North Sumatera in recent years has tended to decrease because of the falling export quantities and commodity prices. In 2017, fruit exports were US\$242,509,000 to US\$208,991,000 in 2008 [6]. Meanwhile, the export of agricultural commodities has a significant effect on the economic growth [7]. Therefore, North Sumatera government needs to encourage regional economic through the development of fruit commodities by identifying high-priority of fruit commodities in each regency.

Fruit commodities can be developed if an area has a competitive advantage, comparative, and specialized for the commodity. Therefore, the aim of this study is (1) to analyze superior fruit commodities in North Sumatera, (2) to analyze specialization and localization of fruit commodities in North Sumatera, and (3) to analyze priority of fruit commodities in North Sumatera.

\section{Research Methods}

\subsection{Sample}

The sample of this research is all regencies or cities in North Sumatera. There are 25 regencies and 8 cities. Hance, there are 33 sample.

\subsection{Data Collection}

Data used in this study are secondary data from 2017 to 2019 obtained from Central Statistical Bureau and Ministry of Agriculture. The data used include production data, price, and production value of fruit commodity. Fruit commodity that being researched are Mango, Durian, Orange, Banana, Papaya, and Salak fruit. They were chosen because this commodity has increased domestic consumption, but imports of this commodity are also relatively high, resulting in a deficit in the agricultural balance.

\subsection{Analysis Tools}

\subsubsection{Analysis of Superior Fruit Commodities in North Sumatera}

Fruit commodity determined by Location Quotient (LQ) analysis. LQ analysis is a comparison between the relative share of commodity production I at the regional level to the total production area of the region with the relative share of commodity production $i$ at the level of region to total production of the region. if $L Q \geq 1$, it means that the regency/city is a commodity base. If $\mathrm{LQ} \leq 1$, it means that the district is not a commodity base [8]. LQ model has the following formula [9]: 


$$
L Q=\frac{x_{i} / n_{i}}{x / n} .
$$

where:

$\mathrm{xi}=$ total production value of fruit commodities at regency/city level

$\mathrm{ni}=$ total production of fruit commodities at regency/city level

$\mathrm{x}=$ total production value of fruit commodities at provincial level

$\mathrm{n}=$ total production of fruit commodities at provincial level

\subsubsection{Specialization Analysis and Localization of Fruit Commodities in North Sumatera}

Specialization Quotient (SQ) and Localization Quotient (LoQ) is used to determine distribution and concentration of fruit commodity production. SQ is used to determine the specialization of an agriculture activity in a district and specialization of certain fruit commodities at the level of North Sumatera. If $\mathrm{SQ} \geq 1$, it means that at the district level there is specialization in agricultural activities for fruit commodities. If $\mathrm{SQ}=0$, it means that fruit commodities are not specialized in some regency. If $\mathrm{SQ}<1$ and close to 0 , it indicates that at the district level there are no specialization of certain agricultural activities. Nevertheless, a positive SQ indicates that the district has a comparative advantage in producing certain agricultural commodities [10]. The formula of SQ [11] is:

$$
S Q=\left\{\left(\frac{S_{i}}{\sum s_{i}}\right)-\left(\frac{N_{i}}{\sum N_{i}}\right)\right\}
$$

where:

$\mathrm{Si}=$ fruit commodities at the regency level

$\mathrm{Ni}=$ fruit commodities production at the province level

$\Sigma \mathrm{Si}=$ total production of fruit commodities at the regency level

$\Sigma \mathrm{Ni}=$ total agricultural production at the national level

LoQ is used to measure the distribution of agricultural commodities development activities in a region. If $\mathrm{LoQ} \geq 1$, there is a concentration of agricultural activities. If $\mathrm{LoQ} \leq 0$, there is no centralization in agricultural activities. Therefore, the priority of fruit commodity is determined from LQ and KS. The LoQ formula is as follows [11]:

$$
L o Q=\left\{\left(\frac{s_{i}}{N_{i}}\right)-\left(\frac{\sum s_{i}}{\sum N_{i}}\right)\right\}
$$

\subsubsection{Analysis of Priority of Fruits Commodities in North Sumatera}

Fruit commodities that become priority is analyzed based on the combination by looking at the highest LQ value and the highest SQ of fruit commodities in each regency. The greater the LQ of commodity, the greater the potential advantage of the commodity. And, if the quotient value is the highest in various commodity that means the commodity has a comparative advantage to be produced in the regency. Fruit commodities that have the highest LQ and highest SQ can be prioritized for better development in an area. 


\section{Result and Discussion}

\subsection{Analysis of Superior Fruit Commodities in North Sumatera}

Based on the results of the LQ analysis in Table 1 shows that of the 6 fruit commodities that being analyzed, Oranges and Salak fruit are the leading commodities with the least amount for several regencies. There are only 4 regions which are the basis of oranges and 3 regions which are the basis of Salak fruit. The rest, such as mangoes, Durians, Bananas, and Papayas are superior commodities in many regions.

Table 1. LQ > Fruit Commodities for Regency/City in North Sumatera

\begin{tabular}{|c|c|c|}
\hline No. & Commodities & Regencies \\
\hline 1 & Mangoes & $\begin{array}{l}\text { Mandailing Natal, Tapanuli Selatan, Tapanuli Utara, Toba } \\
\text { Samosir, Labuhan Batu, Asahan, Deli Serdang, Langkat, Nias } \\
\text { Selatan, Samosir, Serdang Bedagai, Batubara, Padang Lawas, } \\
\text { Labuhan Batu Selatan, Labuhan Batu Utara, Nias Barat, } \\
\text { Tanjung Balai, Pematang Siantar, Tebing Tinggi, Medan, } \\
\text { Binjai, Padangsidempuan, Gunungsitoli }\end{array}$ \\
\hline 2 & Durians & $\begin{array}{l}\text { Nias, Mandiling Natal, Tapanuli Tengah, Tapanuli Utara, } \\
\text { Toba Samosir, Labuhan Batu, Dairi, Nias Selatan, Pakpak } \\
\text { Bharat, Samosir, Serdang Bedagai, Padang Lawas, Labuhan } \\
\text { Batu Selatan, Labuhan Batu Utara, Nias Utara, Nias Barat, } \\
\text { Pematang Siantar, Tebing Tinggi, Binjai, Gunung Sitoli }\end{array}$ \\
\hline 3 & Oranges & Tapanuli Utara, Simalungun, Dairi, Karo, Pakpak Bharat \\
\hline 4 & Bananas & $\begin{array}{l}\text { Nias, Mandailing Natal, Toba Samosir, Asahan, Deli } \\
\text { Serdang, Langkat, Nias Selatan, Serdang Bedagai, Batubara, } \\
\text { Padang Lawas, Labuhan Batu Utara, Nias Utara, Nias Barat, } \\
\text { Tanjung Balai, Pematang Siantar, Tebing Tinggi, Binjai }\end{array}$ \\
\hline 5 & Papayas & $\begin{array}{l}\text { Nias, Mandailing Natal, Toba Samosir, Labuhan Batu, Deli } \\
\text { Serdang, Langkat, Nias Selatan, Samosir, Serdang Bedagai, } \\
\text { Batubara, Padang Lawas, Labuhan Batu Selatan, Labuhan } \\
\text { Batu Utara, Nias Barat, Tanjung Balai, Pematang Siantar, } \\
\text { Tebing Tinggi, Medan, Binjai, Padangsidimpuan, } \\
\text { Gunungsitoli }\end{array}$ \\
\hline 6 & Salak & Tapanuli Tengah, Humbang Hasundutan, Padang Sidempuan \\
\hline
\end{tabular}

Orange is not a basis commodity because for optimal orange cultivation, it requires geographical condition of 400-700 masl. Karo District can be a base for oranges because the area is a plateau. It can be seen from the productivity of orange commodities in one of the districts reached 2.42 quintal/tree [12]. Besides, the expansion of oil palm plantations in North Sumatra could be one factor that makes the area of fruit commodities very limited. In 2005, the area of oil palm plantations was 894,911 hectares to 1,290,977 hectares in 2009 and in that year the portion of land area of oil palm plantations in North Sumatra reached $17.13 \%$ nationally [13].

Karo and Simalungun are areas that are well known as oranges producer. Orange production from Karo reached 56.62 percent of orange production in North Sumatera in 2017. Tapanuli Selatan is famous for Salak fruit. Even in the same year, the contribution of Salak fruit 
production in Tapanuli Selatan reached 89.24 percent of total production of Salak fruit in North Sumatera.

\subsection{Analysis of Specialization and Localization of Fruit Commodities in North Sumatera}

\subsubsection{Mango}

Figure 1 shows the level of specialization and localization (distribution) of mango commodities. Based on SQ mango, it can be seen that there are more than $50 \%$ of districts/cities which has a positive SQ value. This means that more than $50 \%$ of the region has a comparative advantage for mangoes. Nevertheless, none of these $50 \%$ have a SQ $\geq 1$ that indicates the specialization of the mango in a district.

The level of localization or distribution of mango commodities can be seen from the value of LoQ is close to zero and even has a minus value. This is caused by the mango produced in all regencies in North Sumatera with relatively the same level of production. Therefore, the existence of mango commodities tends to spread evenly in districts in North Sumatera.

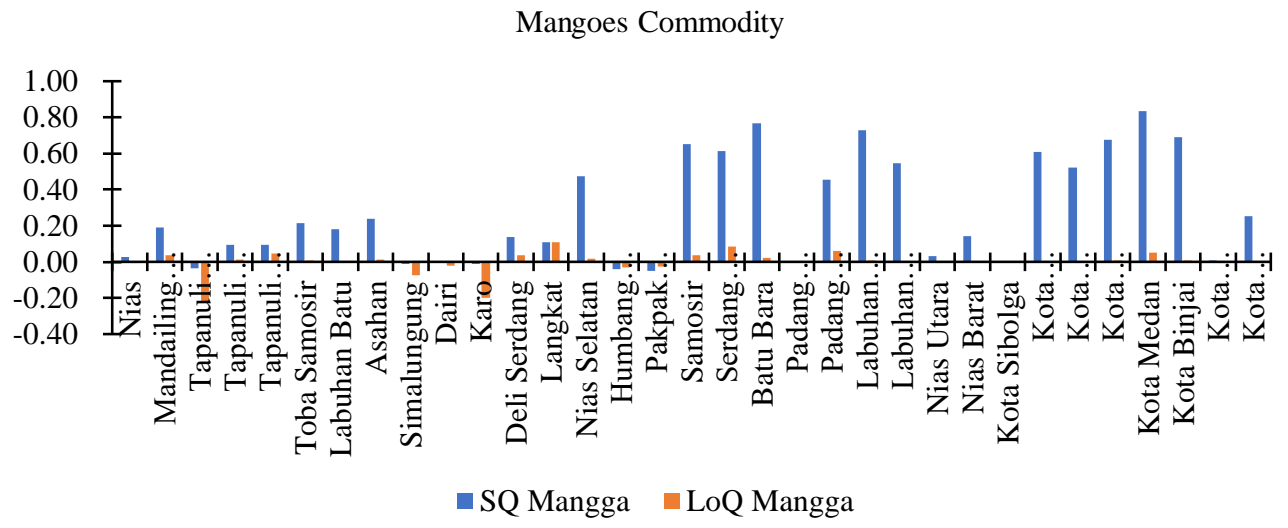

Fig. 1. Specialization and Localization of Mango Commodities in North Sumatera (Results of Analysis).

\subsubsection{Durians Commodities}

Level of specialization of durians is no better than mangoes. There is a fewer comparative advantage in regencies. There are only 6 regencies that have a relatively higher SQ than other regions. Other regions have a negative value (see Figure 2). Durian has not been cultivated specifically by farmers because it is only a plant that grows in the forest without nurturing and people just wait the fruit to be harvested.

Figure 2 also shows that the average LoQ of durians in all regencies is smaller than 1 and some even have a minus value. This is also due to the fact that durian commodities are produced in North Sumatera with relatively the same level of production. Therefore, the presence of mango commodities tends to spread evenly in North Sumatera. 


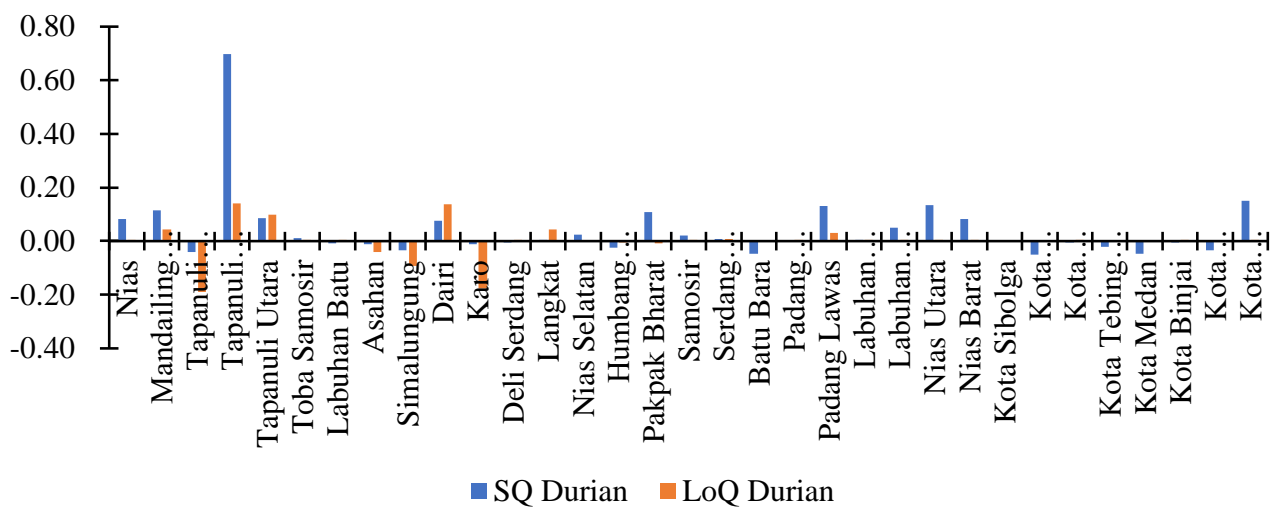

Fig. 2. Specialization and Localization of Durians Commodities in North Sumatera (Result of Analysis).

\subsubsection{Oranges}

SQ and LoQ of oranges are very different from the previous fruit commodities. There are only 5 districts that have a comparative advantage with positive SQ. There are Tapanuli Utara, Simalungun, Dairi, Karo, and Pakpak Bharat (see Figure 3). Nevertheless, in the 5 districts, citrus has not been specialized because the $S Q$ value $<1$. While other regencies have $S Q \leqslant 0$. It means that the production of oranges commodities in many regencies is still relatively small when compared to other fruit commodities.

Based on Figure 3, it can be seen that the LoQ of orange is not > 1, even the LoQ value is closer to 0 . This shows the same thing as the previous fruit commodity, which is the spread of orange production in several regencies is at the same level. However, there are four districts that have relatively high LoQ scores, such as Asahan, Simalungun, Dairi, and Karo, with LoQ values of $0.06 ; 0.08 ; 0.09$; and 0.13 . This is because the oranges are only cultivated in these 4 regencies. Therefore, the concentration rate is relatively high.

Oranges Commodity

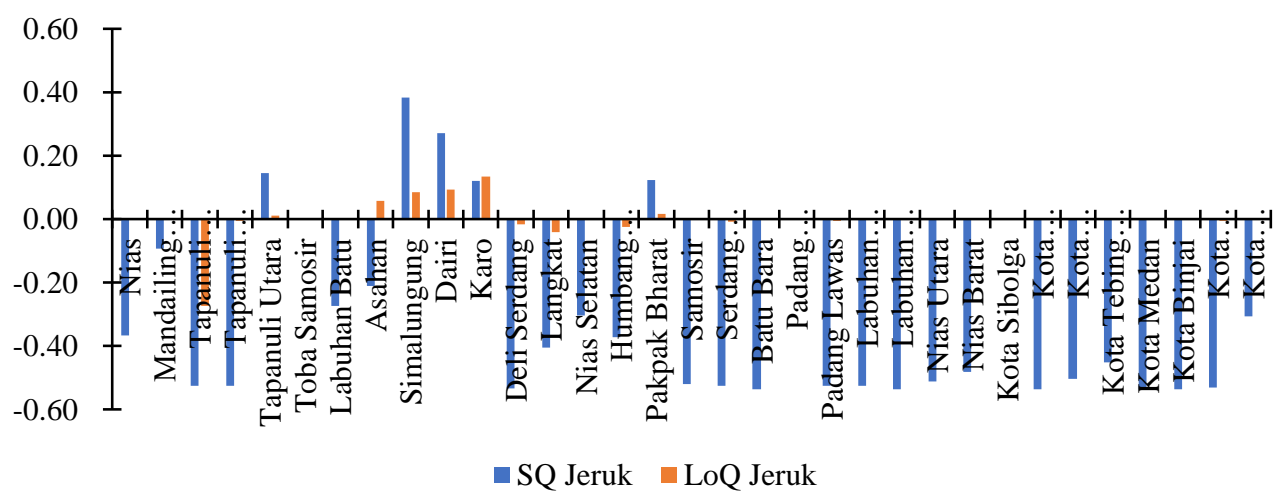

Fig. 3. Specialization and Localization of Orange Commodities in North Sumatera (Result of Analysis). 


\subsubsection{Bananas}

There are only 7 regencies that have a positive SQ of bananas (see Figure 4). This is better that oranges, where is only 5 regencies that have a positive SQ value. The 7 regencies are Nias, Asahan, Langkat, Labuhan Batu Utara, Nias Utara, Nias Barat, and Tanjung Balai. There are several more that have positive SQ values but the numbers are relatively very small. Bananas in 7 regencies has a comparative advantage compared to other fruit commodities. However, the same as the previous fruit commodity, the SQ value $<1$ means that the banana has not been specialized in the 7 regencies.

Langkat has a relatively higher LoQ value of bananas compared to other regions, which is 0.47 (see Figure 4). This is due to the fact that banana is only cultivated in one district, Langkat. Therefore, the concentration rate is high. Banana production in this district reaches 50.35 percent of total banana production in North Sumatera. Another could be due to the price of banana commodities in recent years has increased. Banana prices grow annually at an average of 10.35 percent [14]. Because high prices and production will lead to an increasing value of production of these commodities.

Bananas Commodity

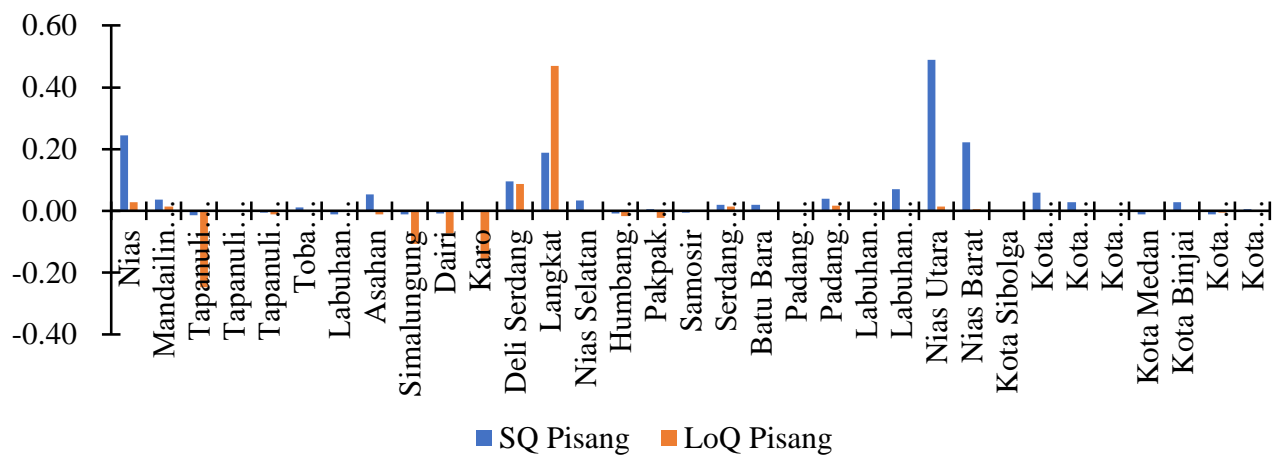

Fig. 4. Specialization and Localization of Banana Commodities in North Sumatera (Result of Analysis).

\subsubsection{Papayas}

Based on Figure 5 it shown that the SQ of papayas is much better than bananas. Many regencies have positive SQ, although they are still less than 1 . This shown that papayas in some regions have a comparative advantage even it has not been specialized. The trend of papaya commodities production in North Sumatera has increased in recent years, e.g., in 2018, total production of papaya amounted to 295,698 tons then in 2019 it became 1,123,277 tons.

Similar to bananas, papayas LoQ is not $>1$ but Langkat district has a relatively high LoQ value compared to other regencies. Because papaya is mostly cultivated in one regency, Langkat. Therefore, the concentration rate is high. 


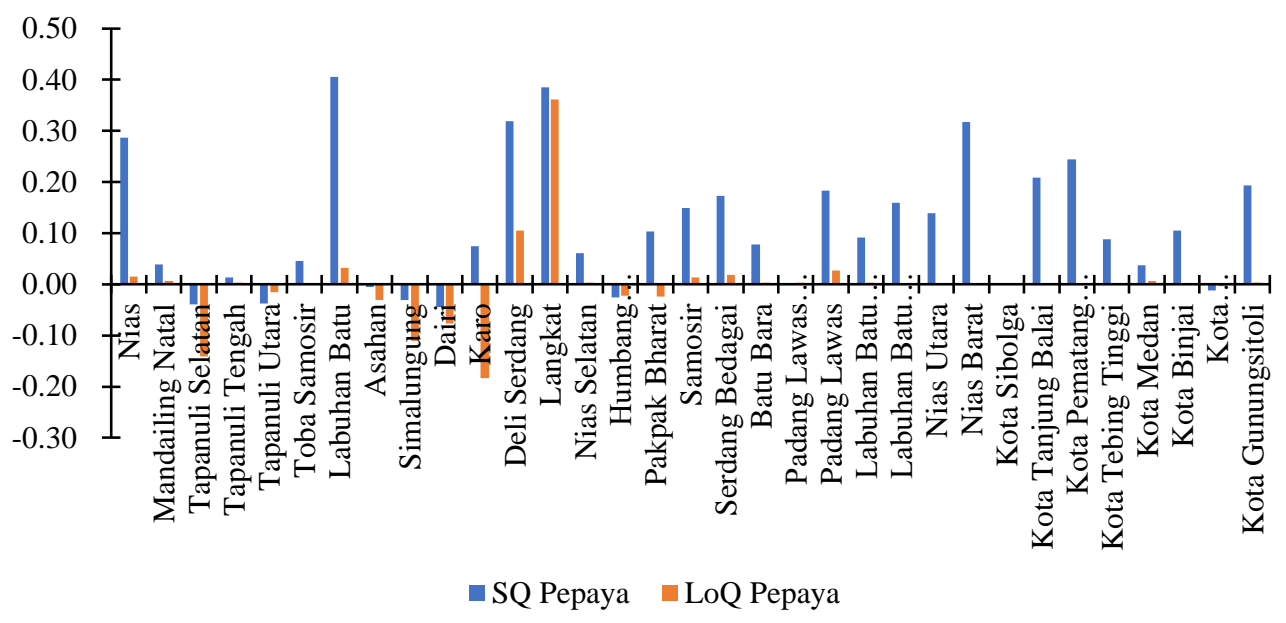

Fig. 5. Specialization and Localization of Papaya Commodities in North Sumatera (Result of Analysis).

\subsubsection{Salak}

SQ and LoQ of Salak fruits commodity in each regency is very different (see Figure 6). There are only 3 regencies that dominate with positive SQ, namely Tapanuli Selatan, Humbang Hasundutan, and Padang Sidempuan, with SQ values 0.64; 0.45; and 0.56, respectively. The figure shows that 3 regencies have a comparative advantage for Salak.

Nevertheless, what's interesting is shown by the LoQ value of Salak. In Figure 6, it can be seen that from 3 regencies above, only Tapanuli Selatan has the highest LoQ value. This is because the production of Salak in Tapanuli Selatan is very high, e.g., in 2017 production of Salak fruit in Tapanuli Selatan reached 1,453,691 tons, while in Humbang Hasundutan and Padang Sidempuan only 113,280 tons and 8,240 tons in the same year [5].

Salak Fruits Commodity

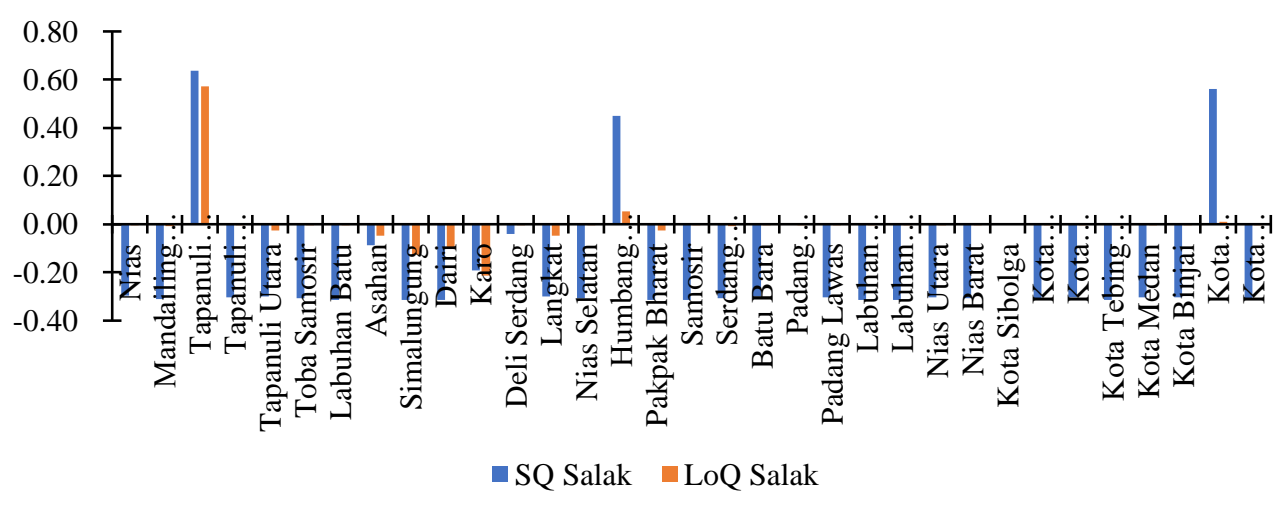

Fig. 6. Specialization and Localization of Salak Fruits Commodities in North Sumatera (Result of Analysis). 


\subsection{Analysis of Priority of Fruits Commodities in North Sumatera}

The criteria for priority of fruit commodities to be developed in each district are commodities with relatively high LQ and SQ values. Based on these criteria (see Table 2):

a) Mangoes is prioritized in: Mandailing Natal, Toba Samosir, Asahan, Nias Selatan,

Samosir, Serdang Bedagai, Batu Bara, Padang Lawas, Labuhan Batu Selatan, Labuhan

Batu Utara, Kota Tanjung Balai, Kota Pematang Siantar, Kota Tebing Tinggi, Kota

Medan, Kota Binjai and Kota Gunungsitoli.

b) Durians are only prioritized in: Tapanuli Tengah.

c) Oranges are prioritized in: Tapanuli Utara, Simalungun, Dairi, Karo and Pakpak Bharat.

d) Bananas are prioritized in: Nias, Nias Utara and Nias Barat.

e) Papayas are prioritized in: Labuhan Batu, Deli Serdang and Langkat.

f) Salaks are prioritized in: Tapanuli Selatan, Humbang Hasundutan, and Kota Padangsidempuan.

Table 2. Priority of Fruits Commodity

\begin{tabular}{|c|c|c|c|c|}
\hline No & Regencies & Commodities & $\mathbf{L Q}$ & SQ \\
\hline 1 & Nias & Banana & 4.51 & 0.25 \\
\hline 2 & Mandailing Natal & Mango & 3.11 & 0.19 \\
\hline 3 & Tapanuli Selatan & Salak fruit & 4.02 & 0.64 \\
\hline 4 & Tapanuli Tengah & Durian & 9.87 & 0.70 \\
\hline 5 & Tapanuli Utara & Orange & 1.13 & 0.14 \\
\hline 6 & Toba Samosir & Mango & 4.80 & 0.22 \\
\hline 7 & Labuhan Batu & Papaya & 14.35 & 0.40 \\
\hline 8 & Asahan & Mango & 3.78 & 0.24 \\
\hline 9 & Simalungung & Orange & 1.94 & 0.38 \\
\hline 10 & Dairi & Orange & 1.46 & 0.27 \\
\hline 11 & Karo & Orange & 1.28 & 0.12 \\
\hline 12 & Deli Serdang & Papaya & 4.27 & 0.32 \\
\hline 13 & Langkat & Papaya & 3.29 & 0.38 \\
\hline 14 & Nias Selatan & Mango & 7.81 & 0.47 \\
\hline 15 & Humbang Hasundutan & Salak fruit & 2.86 & 0.45 \\
\hline 16 & Pakpak Bharat & Orange & 1.26 & 0.12 \\
\hline 17 & Samosir & Mango & 14.50 & 0.65 \\
\hline 18 & Serdang Bedagai & Mango & 12.88 & 0.61 \\
\hline 19 & Batu Bara & Mango & 17.23 & 0.77 \\
\hline 20 & Padang Lawas Utara & N/A & & \\
\hline 21 & Padang Lawas & Mango & 6.24 & 0.46 \\
\hline 22 & Labuhan Batu Selatan & Mango & 16.79 & 0.73 \\
\hline 23 & Labuhan Batu Utara & Mango & 7.26 & 0.55 \\
\hline 24 & Nias Utara & Banana & 4.64 & 0.49 \\
\hline 25 & Nias Barat & Banana & 4.44 & 0.22 \\
\hline 26 & Kota Sibolga & N/A & & \\
\hline 27 & Kota Tanjung Balai & Mango & 10.80 & 0.61 \\
\hline 28 & Kota Pematang Siantar & Mango & 9.40 & 0.52 \\
\hline 29 & Kota Tebing Tinggi & Mango & 15.88 & 0.68 \\
\hline 30 & Kota Medan & Mango & 24.62 & 0.84 \\
\hline
\end{tabular}




\begin{tabular}{llccc}
\hline 31 & Kota Binjai & Mango & 13.56 & 0.69 \\
\hline 32 & Kota Padangsidimpuan & Salak fruit & 3.49 & 0.56 \\
\hline 33 & Kota Gunungsitoli & Mango & 4.03 & 0.25 \\
\hline
\end{tabular}

Source: Analysis of LQ and SQ.

There are several limitations of this study. First, only 5 fruit commodities were used as objects due to the limited data obtained. Second, there were 2 districts that did not have fruit production data. Third, data used in this research only 3 years, 2017-2019. These limitations will give different results if other studies conduct research with the same sample and objects.

\section{Conclusion}

Based on the results of this study indicate that (1) each district in North Sumatera has a fruit base commodity that varies greatly, (2) there are no districts in North Sumatera that specialized in producing certain fruit commodities and produced at a relatively the same in North Sumatera's regency, (3) the priority of fruit commodity is still monotonous because almost 49 percent of regencies with mangoes as priority. Hance, the goal of regional economic development based on horticultural commodities is difficult to achieve because fruit commodities have not been specialized and evenly localized. We need a more comprehensive and specific regional horticultural commodity development plan is needed based on the study.

\section{Acknowledgement}

This study was supported by a research grant from Ministry of Research, Technology, and Higher Education, Indonesia. We also thank to Wilmar Business Indonesia Polytechnic for facilitating us as researchers in this study. We are also grateful for the insightful comments offered by the anonymous peer reviewers. The generosity and expertise of one and all have improved this study in innumerable ways and saved us from many errors, those that inevitably remain are entirely our own responsibility.

\section{References}

[1] N. Zubaedah, D. B. Buchori, and A. Munif, "Keefektifan Kebijakan Pembatasan Pintu Masuk Impor Hortikultura Terhadap Aspek Perlindungan Tanaman," Risal. Kebijak. Pertan. DAN Lingkung. Rumusan Kaji. Strateg. Bid. Pertan. dan Lingkung., vol. 2, no. 2, pp. 143-151, 2015.

[2] E. P. Santosa, M. Firdaus, and T. Novianti, "Dayasaing Komoditas Hortikultura Negara Berkembang dan Negara Maju di Pasar Internasional," J. Ekon. dan Kebijak. Pembang., vol. 5, no. 2, pp. 68-86, 2016.

[3] B. Irawan, "Agribisnis hortikultura: peluang dan tantangan dalam era perdagangan bebas," SOCA J. Sos. Ekon. Pertan., 2003.

[4] A. Pradipta and M. Firdaus, "Posisi daya saing dan faktor-faktor yang memengaruhi ekspor buahbuahan Indonesia," J. Manaj. Agribisnis, vol. 11, no. 2, pp. 129-143, 2014.

[5] Badan Pusat Statistik, "Provinsi Sumatera Utara Dalam Angka 2019," Badan Pusat Statistik, 2019. .

[6] Badan Pusat Statistik, "Statistik Perdagangan Luar Negeri Ekspor Provinsi Sumatera Utara,"
Badan
Pusat
Statistik,
2018.
[Online].
Available: 
https://sumut.bps.go.id/publication/2019/08/09/7eaec8ba485702d5ba72e56f/statistikperdagangan-luar-negeri-ekspor-provinsi-sumatera-utara-2018.html.

[7] D. R. Asbiantari, M. P. Hutagaol, and A. Asmara, "Pengaruh Ekspor Terhadap Pertumbuhan Ekonomi Indonesia,” J. Ekon. dan Kebijak. Pembang., vol. 5, no. 2, pp. 10-31, 2016.

[8] B. Volsi, T. S. Telles, C. E. Caldarelli, and M. R. G. da Camara, "The dynamics of coffee production in Brazil," PLoS One, vol. 14, no. 7, p. e0219742, 2019.

[9] A. Crawley, M. Beynon, and M. Munday, "Making location quotients more relevant as a policy aid in regional spatial analysis," Urban Stud., vol. 50, no. 9, pp. 1854-1869, 2013.

[10] R. Ropingi and Y. Sudartono, "Pembangunan Wilayah Kecamatan Berbasis Komoditas Pertanian di Kabupaten Gunungkidul Propinsi Daerah Istimewa Yogyakarta (Agriculture CommodityBased Sub-District Development In Gunungkidul, Yogyakarta)," J. Ilmu-Ilmu Pertan., vol. 4, no. 2, p. 12,2020

[11] S. Vaulina, "Identifikasi Komoditi Unggulan Pada Sektor Pertanian di Kabupaten Indragiri Hilir Provinsi Riau," J. Agribisnis, vol. 18, no. 1, pp. 42-54, 2016.

[12] E. C. Purba and B. S. Purwoko, "Teknik Pembibitan, Pemupukan, dan Pengendalian Hama Penyakit Tanaman Komoditi Jeruk Siam (Citrus Nobilis Var. Microcarpa) di Kecamatan Simpang Empat dan Kecamatan Payung, Kabupaten Karo, Sumatra Utara, Indonesia," Pro-Life, vol. 6, no. 1 , pp. 66-75, 2019.

[13] D. M. Sinaga and R. M. Hendarto, "Analisis Kebijakan Pengelolaan Perkebunan Kelapa Sawit Di Provinsi Sumatra Utara." Fakultas Ekonomika dan Bisnis, 2012.

[14] Kementerian Pertanian, Outlook Komoditas Pertanian Sub Sektor Hortikultura. Kementerian Pertanian, 2016. 